\title{
Research of Profitable Period for the Jasmine Farmers Based on its Yield Estimation and Market Price using K-Means Clustering Algorithm
}

\author{
K.S. Kousalyaa Devi, S.Gopalakrishnan, R.Anusuya, P. Naveen
}

\begin{abstract}
Jasmine is the oldest fragrance flower and commercial crop of south India. It is mostly used for garlands, perfumes, cosmetic and medicinal purpose. Its use is only for 24 hours. Jasmine grows successful in all season but farmer does not have the proper guidance to cultivate the jasmine in correct climate to cultivate, month to plant and harvest and best fertile soil to plant the jasmine will help the farmers for best cultivation and productivity of jasmine. But without the knowledge the farmer's not get the profit of selling the jasmine in all season. In peak season the jasmine flower is high and the price is low in market and in lean season the flower is low but the market price is high. This is the main reason for the research to choose a particular month in lean season to increase the jasmine flower yield to get more profit to the farmers, and the yield estimation, data sets are collected and calculated using K-Means Clustering Algorithm in data mining.
\end{abstract}

Keywords: Jasmine Yield, Season, K-Means Clustering.

\section{INTRODUCTION}

Tamil Nadu places the $2^{\text {nd }}$ rank in jasmine producing in India and South India, it is from the Oleaceae Family and the Jasminum is the genus. There are 50 types in India but there are only three types are mostly used for profitable growth. They are Sambac(GunduMalli) , Grandiflourm(Malli) , Auriculatum(Mullai).But in hot climate it needs rainfall or the health is from more watering and plant growth. It should plant in the month of June November. The jasmine starts flowering between FebruaryApril. Then decrease in the end of the month August. The 100 jasmine plants are takes for sample planting and it needs 50 cents which is 0.5 acre. It produces 161.87 as approximately per acre. The jasmine color changes is while pluck in early morning it is greenish white color and Milky white after few hours, shiny creamy in evening [1]. Data mining is the process of finding new pattern from huge data sets, this technology which is in use in inferring useful knowledge that can be put to use from a huge amount of data.

Revised Manuscript Received on September 14, 2019.

K. S. Kousalyaa Devi, Student, Dept. of Computer Technology, Sri Krishna Arts and Science College, Coimbatore, Tamil Nadu, India.(E-mail: kousalyaadeviks@gmail.com)

S. Gopalakrishnan, Assistant Proffessor, Dept. of Computer Technology, Sri Krishna Arts and Science College, Coimbatore, Tamil Nadu, India.(E-mail: gopalakrishnans@ skasc.ac.in.)

R.Anusuya, Student, Dept. of Computer Technology, Sri Krishna Arts and Science College, Coimbatore, Tamil Nadu, India.

P. Naveen, Student, Dept. of Computer Technology, Sri Krishna Arts and Science College, Coimbatore, Tamil Nadu, India.

\section{PROBLEM DEFINITION}

The problem defined here is analysis of profitable period for the jasmine farmers based on its yield estimation and market price. Climate and soil plays the important role in agriculture crop yield estimation. The jasmine plant grows in well drained soils or red loamy fertile soil. The soil ph is around 6.5-7.5. Climate for successful cultivation of jasmine is mild winter it Tolerant of limited alkalinity. Grows best in rich organic soil is well drained [3].

Soil thermometer or Soil Probe thermometer is used to measure the temperature of the soil. It measures the temperature it ranges from 0 to $80^{\circ} \mathrm{C}$ [4]. The jasmine plant have the temperature is from 60 to $75^{\circ} \mathrm{F}$. Tensiometer is a measuring device. It is used to measure the moisture tension of the soil. It works best at the soil moisture [5]. The yield estimation of the jasmine is calculated using the specified data mining algorithm used here is K-Means Clustering Algorithm. It is used to separate the data into different clusters containing points with similar characteristics. The below figures are the main problems faced by the jasmine farmers are budworms, leaf webber etc.

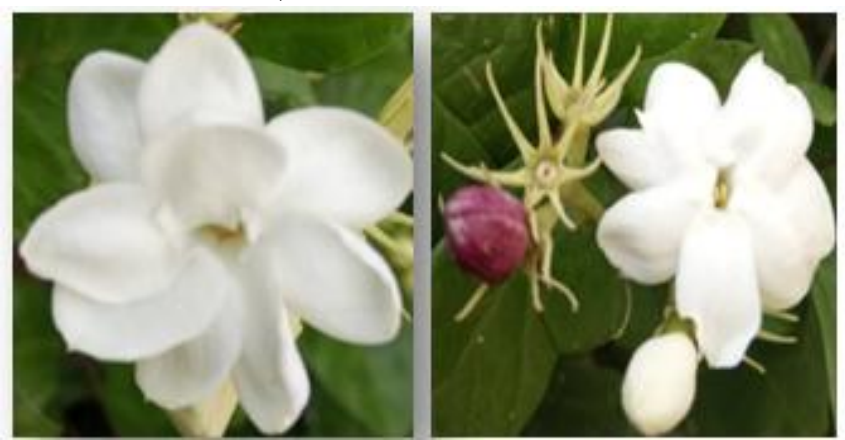

Figure 1 Color of the bud changed to pink

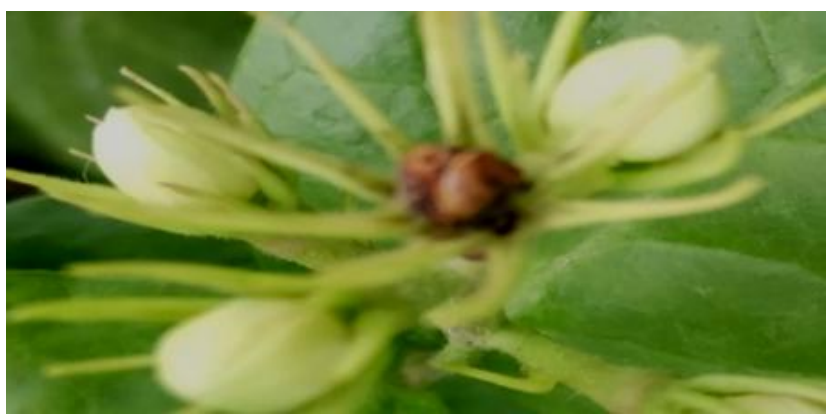

Figure 2Infested buds

Published By: Blue Eyes Intelligence Engineering \& Sciences Publication 


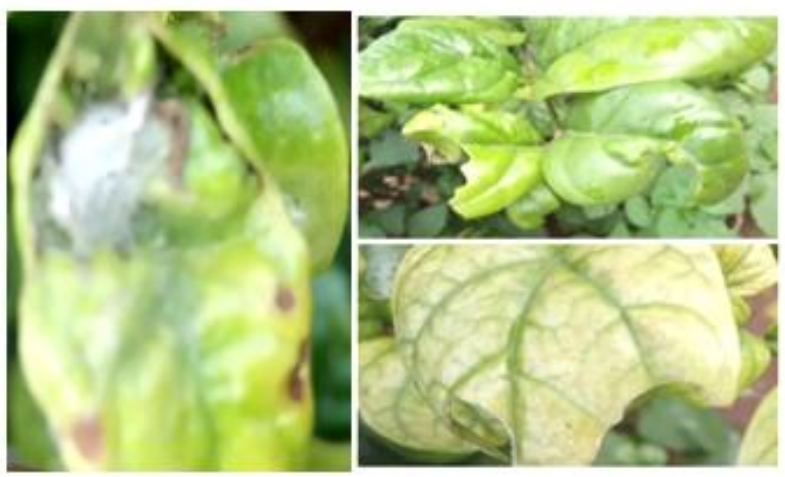

Figure 3 webbing on leaves and leaf webber on leaves

buds of jasmine sambac. The insects found inside the bud. It takes food from the last petal of the closed bud in the start stage. It goes inside through a circular hole made on the hole like tube portion of the petals through something into the next bud. The color is change to pink color of the bud [2].

In the above Figure 3 is leaf webber is named as Nausinoe geometralis is the damage caused in leaf. Caterpillar and adult make the major damages in leaf webber. Caterpillar is mainly in the leaves to scrabble the chlorophyll. It is mainly affected during the rainy season, and it is serious in dry and summer season [2].

\section{LITERATURE SURVEY}

In the above Figure 1, 2 are Budworms is named as

Hendecasis duplifascialis is the greatest damages to green

\begin{tabular}{|c|c|c|c|}
\hline S.No & Title of the paper & $\begin{array}{ll}\text { Authors/year } & \text { of } \\
\text { publication } & \end{array}$ & Highlights \\
\hline 1. & $\begin{array}{llr}\text { Off season } & \text { flower induction } \\
\text { through } & \text { fertigation and } \\
\text { biostimulant } & \text { spray in Jasminum } \\
\text { sambac Ait } & & \end{array}$ & $\begin{array}{ll}\text { S.T. Bini } & \text { Sundar, M. } \\
\text { Kannan } & \text { And } \\
\text { Jawaharlal, } & \text { Theasian } \\
\text { Journal } & \\
\text { Horticulture, Volume } 9 \\
\text { Issue 1 | June, 2014 | } 32-35\end{array}$ & $\begin{array}{l}\text { Discussed about the } \\
\text { jasmine sambac to grow } \\
\text { and dose of fertilizers to be } \\
\text { used to increase the flower } \\
\text { buds and the result is } \\
\text { shown [7] }\end{array}$ \\
\hline 2. & $\begin{array}{l}\text { Analysis of crop yield prediction } \\
\text { using data mining techniques }\end{array}$ & $\begin{array}{l}\text { D Ramesh 1, B Vishnu } \\
\text { Vardhan2, IJRET,Volume: } \\
\text { 04 Issue: } 01 \text { | Jan-2015, }\end{array}$ & $\begin{array}{l}\text { Presented a yield prediction } \\
\text { and it mainly focus on the } \\
\text { season and it also } \\
\text { discussed about different } \\
\text { data mining algorithm [8] }\end{array}$ \\
\hline 3. & $\begin{array}{l}\text { Clustering Analysis for } \\
\text { Appropriate Crop Prediction } \\
\text { using Hierarchical, Fuzzy C- } \\
\text { Means, K-Means and Model } \\
\text { based Techniques }\end{array}$ & $\begin{array}{l}\text { Dr Madhavi } \text { Gudavalli1, } \\
\text { Vidyasree } \mathrm{P} 2, \quad \mathrm{~S} \\
\text { Viswanadha } \\
\text { International Journal of } \\
\text { Advance Engineering and } \\
\text { Research Development } \\
\text { Volume 4, Issue 11, } \\
\text { November -2017 }\end{array}$ & $\begin{array}{l}\text { Discussed about the various } \\
\text { datasets ,clusters and } \\
\text { applying different data } \\
\text { mining algorithm like k- } \\
\text { means, fuzzy C-means.etc, } \\
\text { [9] }\end{array}$ \\
\hline 4. & $\begin{array}{l}\text { Technology Adoption Behaviour } \\
\text { of Jasmine Growers - A Critical } \\
\text { Analysis }\end{array}$ & $\begin{array}{l}\text { Analysis P. Bagya Janani, } \\
\text { R. Premavathi and } \\
\text { D.Puthira Prathap, Journal } \\
\text { of Extension Education, } \\
\text { Vol. 28 No. 1, } 2016 \\
\text { Bagya Janan }\end{array}$ & $\begin{array}{l}\text { Critically discussed about } \\
\text { the crop yield in TN and it } \\
\text { has the annual production, } \\
\text { cultivation areas and has } \\
\text { different cultivation } \\
\text { technologies which is used } \\
\text { for climate condition and } \\
\text { soil types. [10] }\end{array}$ \\
\hline 5. & $\begin{array}{l}\text { A Survey on Crop Yield } \\
\text { Prediction using Data Mining }\end{array}$ & $\begin{array}{l}\text { Mythra.N, } \\
\text { Dr.Velayudham.A, } \\
\text { Dr.Shamila.E.S, } \\
\text { Pavithra.M, Volume-65 } \\
\text { Number-1, } 2018 \text { by IJCTT } \\
\text { Journal }\end{array}$ & $\begin{array}{l}\text { In this the crop yield } \\
\text { prediction and about } \\
\text { different data mining } \\
\text { algorithm and also the main } \\
\text { aim is used for agriculture } \\
\text { field.[11] }\end{array}$ \\
\hline
\end{tabular}

Table 1 Literature Survey 


\section{CROP YIELD PRICE ESTIMATION AND MARKET VALUES OF JASMINE \& RESULTS}

Tamil Nadu is the $2^{\text {nd }}$ highest rank comparing with other countries in order of cultivation flowers area. TN has 20,000 hectares use for cultivation of flower, among these 7,800 hectares is used for cultivated of jasmine. About 60,000 tones of jasmine are produced as annual cultivation of $\mathrm{TN}$. The planting should be done by June to November [1]. The flower takes place in six month after planting may be in March to April. Jasmine starts blooming between Feb to April. Then flower blooming decrease by the end of August. As cultivation of jasmine gives a good yield of only 7 month in a year and the remaining month of the year farmer suffers a lot.

The March to June is the peak Season and has good yield because of Summer Season, so the cultivation of jasmine is good and the sales for poor price. The October to January is the Lean Season of the jasmine and poor yield because of Monsoon Rain, So the jasmine sales for good price. In July, August, September there is no yield and the quantity is too less. In peak season 4580 per day and in Lean season 2580 per day, the average production of jasmine in TN [6].

\begin{tabular}{|l|l|l|l|}
\hline Season & Month & Price & Profit \\
\hline $\begin{array}{l}\text { Peak } \\
\text { Season }\end{array}$ & $\begin{array}{l}\text { March } \\
\text { to June }\end{array}$ & $\begin{array}{l}\text { Rs 19.67 } \\
\text { to } \quad \text { Rs } \\
63.14 \quad \text { Per } \\
\text { Kg }\end{array}$ & $\begin{array}{l}\text { Low profit in May } \\
\text { and High profit in } \\
\text { March }\end{array}$ \\
& & & \\
\hline $\begin{array}{l}\text { Lean } \\
1\end{array}$ & Oct to & $\begin{array}{l}\text { Rs 45 to } \\
\text { Rs 108.62 } \\
\text { Per Kg }\end{array}$ & $\begin{array}{l}\text { Low profit in Oct } \\
\text { and High profit in } \\
\text { Dec. }\end{array}$ \\
\hline $\begin{array}{l}\text { Lean } \\
\text { Season- } \\
2\end{array}$ & $\begin{array}{l}\text { July, } \\
\text { August, } \\
\text { Sept }\end{array}$ & $\begin{array}{l}\text { Rs 200 to } \\
\text { Rs 250 Per } \\
\text { Kg }\end{array}$ & $\begin{array}{l}\text { High Profit in all } \\
\text { three months. }\end{array}$ \\
\hline
\end{tabular}

Table 2 Month, Market Price and Range in Season

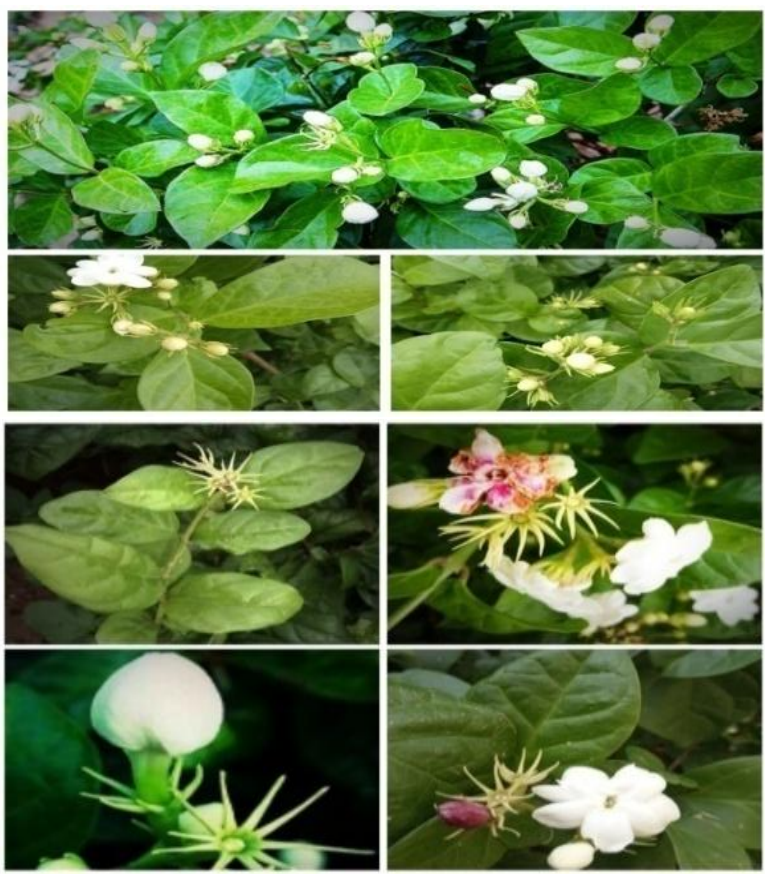

Figure 4 Peak Season and Lean Season
The average production Per Acre in Peak season is 15.27 $\mathrm{Kg}$ and in Lean Season is $8.6 \mathrm{Kg}$ is the calculation of Farmers. Jasmine has the successfully Cultivate in Warm Summer, Mild Winter, and in Sunny days [4].

\section{CONCLUSION}

In this analysis of profitable period of jasmine farmers based on the yield estimation and market price the lean season is the best season for farmer to earn better profit. The main aim is to increase the level of the jasmine in lean season, so October month is chosen and the growth of the jasmine, market price is noted for 100 jasmine plants as sample plants and calculated by using K-Means Clustering algorithm. In future the collected dataset is implemented using data mining algorithm and converted into a website.

\section{REFERENCE}

1 https://www.indianmirror.com/culture/indianspecialties/maduraimalli.html

2 http://agritech.tnau.ac.in/horticulture/horti_flower\%20cro ps_malligai.html

3 http://vikaspedia.in/agriculture/crop-production/packageof-practices/flowers/jasmine

4 https://thermometer.co.uk/home-thermometers/669-soilprobe-thermometer.html

5 https://www.google.com/search?q=tensiometer\&oq=tens iometer\&aqs=chrome..69i57j015.7350j0j7\&sourceid $=\mathrm{chr}$ ome\&ie $=\mathrm{UTF}-8$

6 https://shodhganga.inflibnet.ac.in/bitstream/10603/10289 6/9/09_chapter\%202.pdf

7 off season flower induction through fertigation and biostimulant spray in jasminum sambacait.s.t. bini sundar, $\mathrm{m}$. kannan 1 and $\mathrm{m}$. jawaharlal1, theasian journal of horticulture volume 9 | issue 1 | june, 2014 | 32-35, www.researchjournal.co.in |

8 analysis of crop yield prediction using data mining techniques $d$ ramesh $1, \mathrm{~b}$ vishnu vardhan 2 volume: 04 issue: 01 | jan-2015, available @ http://www.ijret.org 470

9 clustering analysis for appropriate crop prediction using hierarchical, fuzzy c-means, k-means and model based techniques dr madhavi gudavalli1, vidyasree $\mathrm{p} 2$, s viswanadha raju3.

10 international journal of advance engineering and research development volume 4, issue 11, november -2017 ,scientific journal of impact factor (sjif): 4.72

11 technology adoption behaviour of jasmine growers - a critical analysis, p. bagya janani, r. premavathi and d.puthira prathap, journal of extension education, vol. 28 no. 1,2016 